\title{
Omani Students' Application of the Second Standard for Technology Coaches in Internship Program
}

Ahmed Y. Abdelraheem* \& Talal S. Amir Sultan Qaboos University, Sultanate of Oman

Received: 5/6/2015

Revised: 5/9/2015

Accepted: 10/9/2015

Abstract: The aim of this study was to investigate the extent to which Omani students apply International Society for Technology in Education (ISTE) second standard for technology coaches and its relation with gender, training institution type, student's specialization, GPA and cohort. A questionnaire of twenty three items to measure the components of the second standard was derived from these components and used. A sample of 171 students was used to collect data. Onsite supervisors were used to evaluate students' application of the second standard. The results indicate that the overall performance of the students reflects a reasonable and acceptable performance but does not reach the target and desirable performance. Statistical analysis shows no significant differences due to gender, and cohort but there were significant differences due to students' specialization, institution type and students' GPA. The study concludes with some recommendations to improve the weak components and revise the procedures and processes of the internship program.

Keywords: ISTE standards, internship, technology coaches, Omani students.

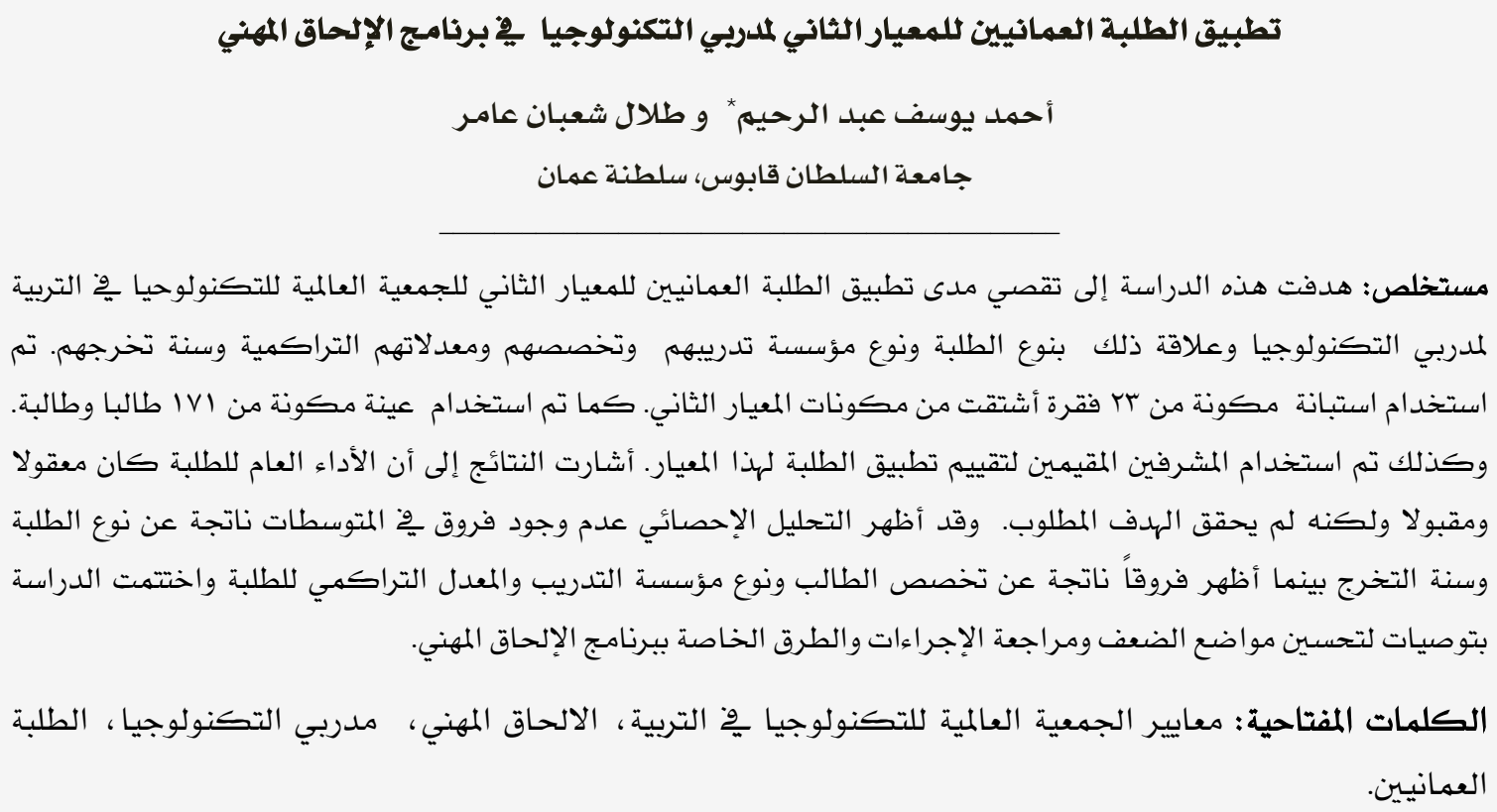

*ahmedyar@squ.edu.om 
The history of student internships originated in the U.S. in the early twentieth century (Driscoll, 2006). According to Thiel and Hartley (1997) the university of Cincinnati's cooperative education program developed the first college-endorsed internship program in the USA in 1906. The program was developed based on the premise that college students pursuing a professional program of studies needed to find a way to finance their education. The first framework of managing the practical experience element was adapted in the field of education where a major requirement of the teaching certification is practice. Internships are career-oriented curricular endeavors of practical application. Internships also address the issue of "lack of practical application" by giving students an active learning experience in the workplace. Students are able to develop the various applied workplace skills they will need to enable them to make a smooth transition from the classroom to the world of business. Feedback from the aggregated evaluations can be used to revise the curriculum in order to improve student performance and meet employers' needs and expectations (Divine, Miller \& Wilson, 2015). Internships are work-based learning experiences that relate to future professions. Students are placed as interns with a wide variety of sponsoring organizations based on their individual fields of interest. These organizations can serve internships in the arts, education, health, communications, business and industry, technology, and many other areas. Students are released from school for part of the school day or school year and work a variable number of required hours on a part-time basis for a designated period. Student interns receive on-the-job, one-on-one training in a work setting from skilled professionals, who provide the knowledge and expertise of their field. Students learn by doing in actual situations through direct, hands-on experiences. They are evaluated and assessed by both their school internship coordinator and their on-site professional supervisor or mentor using an authentic, competency- and performancebased model, portfolios, and exhibitions. Among the many positive educational outcomes of internships are practical experiences, new skills, and improved attitudes and behaviors (Merritt, 2008).

Bukaliya (2012) pointed out that internships are any carefully monitored piece of work or service experience in which an individual has intentional learning goals and reflects actively on what she or he is learning throughout the experience or duration of attachment. Hendrikse (2013) indicated that the benefits of completing an internship include gaining valuable work experience, having an edge in the job market, an opportunity to decide if this is the right career choice and it is a valuable way to build confidence and gain experience. Amir \& Ismail (2014) indicate that the internship program plays a significant role in developing the interns' skills and makes them better prepared for a future career. They added that clear and achievable objectives, experienced site-supervisors, orientation, continuous evaluation and feedback throughout the internship period are major factors for a successful internship program.

Most definitions of the concept of internships have been consistent, making it simple to explain the term. According to Furco (1996), internships are defined as programs that engage students in service activities primarily to provide them with hands-on experience that enhances their learning or understanding of issues relevant to a particular area of study. Meanwhile, McMahon and Quinn (1995) noted that internships are supervised work experiences whereby students leave their institutions and become engaged in work-related programs, during which period they are closely supervised by experienced job incumbents. Internships are therefore any carefully monitored piece of work or service experience in which an individual has intentional learning goals and reflects actively on what she or he is learning throughout the experience or duration of attachment.

The internship program described in this study is designed for undergraduate students to gain work experience, that is, experience gained through the workplace as opposed to experiences students gain in lectures and classrooms. Thus, the term Work-Based Learning (WBL) will be broadly used to encompass these experiences, and the literature on WBL is also included to explore the importance of internship programs for undergraduates. Internships can be used as a pedagogical tool. Student interns are employed and receive on-thejob, one-on-one, practical training in hands-on learning experiences. They work with and learn from skilled professionals in a work setting, which provides them opportunities to 
associate with the people and the resources that can make work real (Littke, 2004). The job-site professionals provide interns with assignments and responsibilities that will allow them to serve as assistants. Students are exposed to workplace environments, norms of the workplace, work expectations, and obligations (Wynn, 2003). Students participate in meetings and get a feel for what work days are like in their field of interest.

Although the majority of higher education institutions offer internship programs for their students, the exact nature of each program may differ based on the aims and objectives set by the respective institutions. However, all internship programs are mainly formed to provide undergraduates with the opportunity to experience and gain practical knowledge in authentic, professional environments before they graduate. In general, internship programs attempt to merge students' learning gained in a campus-based environment with a real-work environment. Thus, terminologies used to describe this relationship between learning and work become important. Terms such as workrelated learning, workplace learning, and work-based learning (WBL) have been used to discuss and describe internship programs. However, the similarities and differences of these terms are not entirely clear (Streumer \& Kho, 2006).

Barron, Dawson, \& Yendol-Hoppey (2009) surveyed a Microsoft program workshop in Florida. The Survey results revealed that many coaches did not perceive that computers changed the role of the classroom teacher. This view suggests a lack of deep understanding about technology integration. They suggested that the program could be substantially improved by helping the coaches think more deeply about technology integration. In addition, most of the coaches and facilitators who attended the workshops were enthusiastic about the peer coaching concept and had positive attitudes about the integration of technology. However, the perpetual issues of adequate time and resources for the implementation of peer coaching and the integration of technology in K-12 classrooms were recurring themes.

Bradshaw (2002) concludes his study with recommendations for strengthening technology initiatives to increase the likelihood that they will result in better coaching of teaching and learning. Swan \& Dixon (2006) investigated the influence of a mentor-supported model of technology training on mathematics teachers' attitudes and use of technology in the classroom. The treatment included six coaching sessions, informal focus groups, and mentorprovided support. The results indicated that mathematics teachers male and female participating in mentor-supported, professional development increased the amount and level of technology use in their practice. Teachers had a desire to learn about technology and understood it was important.

In a study by Holahan, Jurkat, and Friedman (2000), 34 teachers from 33 New Jersey schools were trained not only to use new technology but also to serve as coaches of other teachers at their home schools. The results showed that a mentor-based teaching model permitted greater efficiency as compared to traditional training approaches. The program emphasized mutual sharing, learning, and collaboration versus superior-subordinate relationships between the mentors and those who attended training. Felicen, Rasa, Sumanga \& Buted (2014) utilized the descriptive qualitative design using 50 percent of the interns of second semester 2012-2013 as participants in the area of food and beverage and travel agencies. Results of the study revealed that interns have a satisfactory level of academic performance. In training performance they were rated as very good in terms of knowledge, skills, attitude and personality. Their study also revealed that there is no significant relationship between academic performance and training performance. Martinez, et al (2014) found that Mass Communication students obtained an excellent performance rating in their On-the-Job Training with a high academic performance rating in media marketing and average in advertising principle. Students with high academic performance in Advertising Principle also obtained high training performance except in adherence. Yeswa, Okaka, Mutsotso, Odera \& Mumbo (2012) conducted a study in Kenya to assess whether the contextual factors influence the relationship between internship programs and performance of public healthcare institutions. They found a significant positive relationship between contextual factors and internship programs in public healthcare institutions $(\mathrm{r}=0.501 ; \mathrm{P}<0.05)$. 
Walo (2001) assessed students' perceptions of their level of management competence, before and after the internship component of their degree program. A self assessment instrument utilizing the management competencies within the competing values was used for the empirical stages of the study. The research implies that the internship program has proved effective in contributing towards the development of management competencies for this cohort of students. The study provides valuable insight into the relationship between internship and the development of students' management competencies and highlights the need for further research in this area.

Regarding students' academic performance and success on internship, Callanan and Benzing (2004) posit that there is evidence that students with higher GPAs are more likely to pursue an internship, although it is unclear whether or not they benefit to a greater extent than do students with lower GPAs. Kim, Kim, and Bzullak (2012) found 2.5 or higher to be the most popular GPA prerequisite for internship in accredited schools. Hergert (2011) found a strong correlation between the perceived value of the internship and the student's age and GPA, as older students with higher GPAs had higher perceived values of business internship than did younger students with lower GPAs at a large, public, USA university. On the other hand, Gault et al. (2000) found that major area of study, GPA, and gender were not correlated with the extrinsic measures of career success for the undergraduate business alumni. Hayes (1981) found no relationship between a student's GPA and the completion of required work experience. Also, Casado (1991) suggested that GPA is not a predictor of success or achievement in a hospitality curriculum. In terms of program preparedness Beard and Morton (1999) found academic preparedness to correlate with successful outcomes of a mass communication internship program. Cannon and Arrnold (1998), however, found that students with lower GPAs believed more strongly that an internship in marketing should lead to a full-time job.

Although the literature is rich with studies that investigated and assessed the value of internships in different settings, few studies empirically investigated the influence that individual characteristics could have on such a value. Furthermore, the findings of the limited number of empirical studies that investigated that influence on the perceived value of internship appear to be inconsistent. Therefore, there is a need for more studies that empirically investigate the influence of the individual characteristics on the perceived value of internships in order to enhance our understanding of such influence and help design effective internship programs.

The above studies outline the value and variety of the benefits enjoyed by those students participating in internships, including a better understanding and knowledge of the tasks and practices performed by industry professionals, improved self-confidence, enhanced employment and professional growth opportunities, the ability to network within the industry by creating personal contacts, exposure to management activities, and the development of skills relevant to their particular career choice. Furthermore, internships provide an opportunity for students to apply classroom theories to practical issues in the actual business setting, and most importantly to evaluate whether their career choice is compatible with their interests and personality. These studies did not touch directly the topic investigated by this study, namely the International Society for Technology in Education (ISTE) standards application.

Recently, Sultan Qaboos University (SQU), the national university in the Sultanate of Oman, invested a considerable amount of money to purchase educational technology software and hardware (WebCT, blackboard learning systems, computer labs, and computers at every teaching room with different projectors) that will be used in teaching and learning. This development is accompanied by comprehensive revisions of the curriculum of the College of Education to obtain the accreditation of the National Council for Accrediting Teachers' Education (NCATE), which is changed to Council for Accrediting Educators' Programs (CAEP). All these efforts are expected to increase the productivity of the instructional process and the overall educational outputs of the university. Students are supposed to use these benefits and technologies in the learning process. Simply having the technology resources in the school does not necessarily mean that the staff will use them in their teaching. Educational planners wish to increase the use of technology by students when they leave school and enter the work life. 
The Instructional and Learning Technologies Department (ILTD) in the College of Education, SQU, was established in 2005. The department strives to achieve excellence in its provision of teaching, research, and societal services in the field of instructional and learning technologies. Currently, the department is offering B.Ed in Instructional and Learning Technologies to meet the potential need for information technology teachers and learning resources centers at both basic education and general education levels in the Sultanate of Oman. The department program is undergoing an accreditation process by CAEP by the use of the ISTE standards for coaches.

Internship at the ILTD of the College of Education, SQU, started in the summer of 2008 with 18 students distributed among 6 government and private sector institutions. By the end of the summer 2014, the total number of students who were offered the internship opportunity increased to 211. The internship institutions reached 38 institutions. The main objective of this program is to provide students hands-on experience that relates to their future positions. The nature of the internship of ILTD is slightly different from the normal internship program. In this internship program, the students play two roles. They become trainees at the beginning of the program, and they become trainers at the second part of the internship period, which is two months. They play double roles. Students' evaluation was based on on-site professional supervisors' report, students' daily report, and the university faculty member who administers the program. The work of the intern is an integral part of the student's course of study. No grades are provided for this internship, but it is a required course for student graduation.

ISTE is a premier, nonprofit organization that serves educators and education leaders committed to empowering connected learners in a connected world. ISTE has five sets of standards for each individual who wants to work with technology. These standards are as follows:

- ISTE Standards for Students

- ISTE Standards for Teachers

- ISTE Standards for Administrators

- ISTE Standards for Coaches
- ISTE Standards for Computer Science Educators

Our emphasis in this study is on ISTE standards for coaches. These standards have eight dimensions, and specifically our focus is on the second standard. This second standard focuses on teaching, learning, and assessing technology. In this standard, technology coaches assist teachers in using technology effectively for assessing students' learning, differentiating instructions, and providing rigorous, relevant, and engaging learning experiences for all learners. Technology coaches help bridge the gap from where we are to where we need to be. The ISTE Standards for coaches describe the skills and knowledge they need to support their peers in becoming digital age educators.

\section{Importance of the study}

The importance of this study stems from the nature of the topic under study. It is the first study in this area to the best of the researcher's knowledge and there are no previous studies for the variables considered for this study. Coaching support for teachers is a powerful means of both modeling and harnessing the potential of technology to improve teaching and learning. Teachers who receive coaching in the use of technology tools to improve student learning, and who learn from and collaborate with peers via professional learning communities, will develop confidence and effectiveness in designing and supporting technology-rich environments that maximize student learning. Therefore, the importance of this study could be viewed as follows:

- It will cast light on the internship program by showing how technology coaches practice their roles at the internship institutions.

- The findings of this study will be useful for accreditation process by providing useful data on the application of the second standard for technology coaches.

- ILTD will benefit from this study in determining the weaknesses and strengths of the preparation program and take action where necessary.

- The findings of this study will help in showing if there are any differences in internship institutions, students' cohort, 
and gender and how these differences could be treated.

\section{Statement of the Problem}

Internships have been hailed for integrating classroom education with practical experience in enabling graduates to develop their professional knowledge and professional skills (Beard, 1998). However, unlike the conventional system and owing to a diversity of factors in an educational setting, the concept has encountered challenges. The reason for evaluating internship is to determine its effectiveness. When the evaluation is done, we can hope that the results are positive and gratifying, both for those responsible for the program and for upper-level managers who will make decisions based on their evaluation of the program. Therefore, much thought and planning need to be given to the program itself to make sure that it is effective. The internship program at ILTD has never been evaluated in terms of ISTE standard since its establishment in 2008. This is the first time for this program to be evaluated according to the ISTE second standards for technology coaches (teaching, learning and assessment). As mentioned before, ILTD program is currently undergoing an accreditation process using ISTE standard as SPA (ISTE Standards for Coaches). Therefore, there is a need for this study especially at this time. The study might cast light on the current practice of the internship program in the second standard. This standard is central to the program since the graduates of this program will work in the future as information technology teachers or learning resources specialists. In both positions they are required to coach teachers at school in technology utilization. Therefore the study focuses on uncovering the extent to which the students apply the ISTE second standard for coaches (teaching, learning, and assessments of technology). Having these concerns in mind, this study seeks to answer the following research questions:

1. To what extent do student interns apply the ISTE second standard for technology coaches in internship institutions as viewed by their supervisor?

2. Do student interns' applications of the second standard vary according to student interns' gender, type of internship institution, academic specialization, GPA, and internship year (cohort)? NB: cohort is a very old-fashioned word, little used these days. I'm not sure what you mean by this word. Maybe group? Intake?

\section{Instrument}

The ISTE second standard for technology coaches (Appendix 1 ) consists of eight elements (components), which have been broken down into twenty-three Liker-type items of five points (strongly agree to strongly disagree) to make assessments easier. They constitute the questionnaire (contact the authors for the questionnaire). The questionnaire was given to a panel of faculty members who specialized in educational technology to assess its face validity. They suggested minor revisions, and the researchers fixed them. The reliability coefficient of the instrument was found to be 0.89 based on Cronbach's alpha. The instrument also contains demographic information (gender, specialty, year of internship, and type of institution) about the students and their supervisors who participated in the study. Thereafter, the questionnaire was distributed to the population of the study to respond to its items. The researcher contacted the population through e-mail and telephone calls to urge them to respond to the questionnaire. Collecting the data from the population took two months.

\section{Population}

The population of this study consists of 171 student interns (50 male and 121 female), which is the total number for the last four years (2011 to 2014), and 53 on-site supervisors (35 male and 18 female). A total of 140 students obtained their internship at training institutions supervised by 39 supervisors, and 31 obtained their training at educational institutions supervised by 14 supervisors.

\section{Results and Discussion}

The means and standard deviations of the first question, namely, "To what extent do student interns apply ISTE second standard for technology coaches in internship institutions as viewed by their supervisor?" were calculated, as shown in Table 1:

Table 1 shows that the first element, element (a), has the highest mean (4.13), which means that the supervisors believe that the student interns did well in this element. This result could be attributed to the number of courses 
(four courses) that deal with content and student technology standards in their degree plan. Element (h), which deals with research skills, came at second rank. This result could be explained by the fact that these students have been exposed to many courses that developed their research skills inside and outside the department. The elements with relatively low means are (d) and (f). Element (f) deals with instructional design skills, and this element has only two courses in the degree plan. Element (d) deals with creativity, higherorder thinking skills and processes, and mental habits. This element has no specific courses and is distributed over the whole program. Table 2 shows that the overall performance of the students in the second ISTE standard for technology coaches has a mean value of 3.88 , which reflects a reasonable and accepted performance but not the target and desirable performance which is 5 points as indicated in the questionnaire. The ILTD program also requires more revisions to fix the weak areas and reach the target performance. More work should be done in Coaching teachers in and modeling design and implementation of technology-enhanced learning experiences emphasizing creativity, higher-order thinking skills and processes, and mental habits (e.g., critical thinking, metacognition, and self-regulation.) Also an emphasis should be given to coach teachers in and model incorporation of research-based best practices in instructional design when planning technology-enhanced learning experiences.

To answer the second question which states: "Do student interns' applications of the second standard vary according to student interns' gender, type of internship institution, academic specialization, GPA, and internship year?", t-test was performed for the three variables of the second question, namely, gender, type of internship institution, and academic specialization. The results are shown in Table 2.

\section{Table 1}

Means and standard deviations of students' responses

\begin{tabular}{|c|c|c|c|}
\hline Elements of the second ISTE standard for technology for coaches & $\mathrm{N}$ & Mean & Std. \\
\hline $\begin{array}{l}\text { a. Coach teachers in and model design and implementation of technology-enhanced learning expe- } \\
\text { riences addressing content and student technology standards. }\end{array}$ & 171 & 4.13 & .65 \\
\hline $\begin{array}{l}\text { h. Coach teachers in and model effective use of technology tools and resources to systematically } \\
\text { collect and analyze student achievement data, interpret results, and communicate findings to im- } \\
\text { prove instructional practice and maximize students' learning. }\end{array}$ & 171 & 4.01 & .87 \\
\hline $\begin{array}{l}\text { c. Coach teachers in and model engagement of students in local and global interdisciplinary units } \\
\text { in which technology helps students assume professional roles, research real-world problems, col- } \\
\text { laborate with others, and produce products that are meaningful and useful to a wide audience. }\end{array}$ & 171 & 3.96 & .79 \\
\hline $\begin{array}{l}\text { e. Coach teachers in and model design and implementation of technology-enhanced learning expe- } \\
\text { riences using differentiation, including adjusting content, process, product, and learning environ- } \\
\text { ment based upon student readiness levels, learning styles, interests, and personal goals. }\end{array}$ & 171 & 3.87 & .69 \\
\hline $\begin{array}{l}\text { g. Coach teachers in and model effective use of technology tools and resources to continuously } \\
\text { assess student learning and technology literacy by applying a rich variety of formative and sum- } \\
\text { mative assessments aligned with content and student technology standards. }\end{array}$ & 171 & 3.83 & .77 \\
\hline $\begin{array}{l}\text { b. Coach teachers in and model design and implementation of technology-enhanced learning expe- } \\
\text { riences using a variety of research-based, learner-centered instructional strategies and assessment } \\
\text { tools to address the diverse needs and interests of all students. }\end{array}$ & 171 & 3.80 & .80 \\
\hline $\begin{array}{l}\text { d. Coach teachers in and model design and implementation of technology-enhanced learning expe- } \\
\text { riences emphasizing creativity, higher-order thinking skills and processes, and mental habits (e.g., } \\
\text { critical thinking, metacognition, and self-regulation). }\end{array}$ & 171 & 3.77 & .68 \\
\hline $\begin{array}{l}\text { f. Coach teachers in and model incorporation of research-based best practices in instructional de- } \\
\text { sign when planning technology-enhanced learning experiences. }\end{array}$ & 171 & 3.67 & .73 \\
\hline 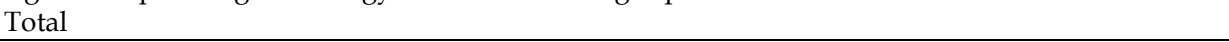 & & 3.88 & .46 \\
\hline
\end{tabular}


Table 2

T-test for differences in means caused by gender, type of institutions and academic specialization

\begin{tabular}{lcccccc}
\hline Variables & $\mathrm{N}$ & $\mathrm{Mean}$ & $\mathrm{SD}$ & $\mathrm{T}$ & $\mathrm{df}$ & Sig. \\
\hline Male & 50 & 4.0137 & .45825 & .756 & \multirow{2}{*}{169} & .450 \\
Female & 121 & 3.9537 & .47643 & & & \\
Educational & 31 & 4.1795 & .52219 & 2,776 & 169 & .006 \\
Training & 140 & 3.9252 & .44747 & & \multirow{2}{*}{0040} \\
IT teachers & 145 & 3.9400 & 47480 & -2.069 & 169 & .040 \\
LC specialists & 26 & 4.1455 & .41283 & & \\
\hline
\end{tabular}

Table 3 shows that no significant differences exist in the means between the male and the female $\left(\mathrm{t}_{169}=.756, \mathrm{p}>0.05\right)$ (mean $=4.01$ for male and mean $=3.95$ for female). This result means that female and male students apply the ISTE standards for teaching, learning, and assessing technology in a similar way without differences. This result could be justified by the fact that both of them received the same training in the Department of Instructional and Learning Technologies. This result agrees with Gault, Redingtion, \& Schlager (2000). They found that gender was not correlated with the extrinsic measures of career success for the undergraduate business alumni. This result is inconsistent with that of Ju, Emenheiser, Clayton, \& Reynolds (1998), who found that gender was an important factor that influenced students' perception of their internship experiences. Males were more satisfied with their internship experiences than females. Males tended to have a stronger resolve to work in the hospitality industry than females. They added that in Korea, it may be very difficult for female college graduates to be offered management positions by hospitality and other companies. Many female hospitality management graduates are employed as entrylevel employees even when they exhibit greater potential than male graduates.

Concerning the comparison between the training institution, Table 3 shows significant differences in means between institution type ( $\left.\mathrm{t}_{169}=2.77, \mathrm{p}<0.05\right) \quad($ mean $=4.17$ for educational institution and mean $=3.92$ for training institution), which means that students who were offered the opportunity to undertake their internship at educational institutions showed greater application of the ISTE standard for teaching, learning, and assessing technology than their fellows who obtained their training at non-educational institutions. This result agrees with the findings of Yeswa, Okaka, Mutsotso, Odera, \& Mumbo (2012). They found a significant positive relationship between contextual factors and internship program in public healthcare institutions. This means that contextual factors influence internship program in public training institutions and facilitate the use of internship program to achieve the intended objectives. This result could be justified by the fact that in educational institutions, students had the chance to show and apply their skills in the application of the ISTE standard more than their fellows in other institutions. This result could also be justified by the fact that the nature of the educational programs at educational institutions focuses on instructional topics, such as designing learning environments, instructional design, electronic management systems, and digital photography. These topics are fully covered in their study plan, whereas at noneducational institutions, the concentration is on topics such as special software serving their needs, networking, human resource development, and other systems for managing companies and institutions.

Concerning the comparison between students' track of study, IT teacher against learning center specialists in applying ISTE standards for teaching, learning, and assessing technology in internship program. Table 3 shows a significant difference in the application of ISTE standards $\left(\mathrm{t}_{169}=-2.06, \mathrm{p}<0.05\right)$ between learning center specialists $($ mean $=4.1455)$ and instructional technology teachers (mean = 3.9400). This result disagrees with Parsa, Aghazadeh, Nejatisafa, Amini, Mohammadi, Mostafazadeh, \& Moghaddam, (2010). They found that there was no significant difference between pediatrics, gynecology, psychiatry, and general practice among the two groups in medical internship program. Also, it disagrees with Gault et al. (2000) who found that major area of study, was not correlated with the extrinsic measures of career success for the undergraduate business alumni. This result could be justified by the fact that learning center specialists have more in technology courses, such as networking, multimedia, and more hands-on laboratory work. They usually take their internship in educational institutions that meet their interests. 
To determine the differences in means between students' GPA and differences in students' cohort, the ANOVA test was used. Table 3 shows the results of the differences in means caused by the GPA variable.

Table 3

ANOVA test for students' GPA variable

\begin{tabular}{lccccc}
\hline Source & SS & df & MS & F & Sig. \\
\hline Between & 5.466 & 2 & 2.733 & 14.263 & .000 \\
$\begin{array}{l}\text { Groups } \\
\text { Within }\end{array}$ & 32.189 & 168 & .192 & & \\
$\begin{array}{l}\text { Groups } \\
\text { Total }\end{array}$ & 37.655 & 170 & & & \\
\hline
\end{tabular}

Grade point average in particular is important to examine for students participating in internships, due to both its link to retention and the link between retention and gainful employment. While the rationale for internships is focused on career-related outcomes, GPA plays an essential role in the link between internship participation and the job market. Table 3 shows that a significant difference exists in means between the students' application of ISTE standard for teaching, learning, and assessing technology caused by their GPA $\left(\mathrm{F}_{2,168}\right.$ $=14.26 \mathrm{p}<0.05)$. The result agrees with Martinez et al, (2014) who found that students with high academic performance in advertising principle also obtained high training performance except in adherence to company policy. In addition, it agrees with Hergert (2011) and Callanan and Benzing (2004). But it disagrees with the findngs of Felicen, Rasa, Sumanga \& Buted (2014), Buted, Felicen, \& Manzano (2014), Casado (1991) and Hayes (1981) who found that there is no significant relationship between academic performance and training performance. Also, this study disagrees with Coutinho (2007) who found no relationship between performance goals and GPA. GPA might be one measure of success, but does not necessarily embody determination or career success as found by Beard and Morton (1999). Although Beard and Morton found that GPA was a less important predictor of internship success, Bacon (2006) found that GPA was a valuable indicator of job success.

In order to know which group of students perform better than others, Scheffe's multiple comparisons were used. Table 4 shows that the applications of the standard for teaching, learning, and assessing technology of students with high GPA were found to be significantly greater than those of their counterparts (aver- age- and low-GPA students). The results also show that the applications of the ISTE standard for teaching, learning, and assessing technology of students with average GPA were found to be significantly greater than those of low GPA students. These results could be justified by the fact that during the program of study, high and average GPA students usually exerted more efforts on their studies, which were reflected in the internship program performance. Those students usually reflect on their performance and apply ISTE standards the way they should be applied. This implies that those students with high final grades in courses have also high performance on job training.

Table 4

Scheffe's multiple comparisons

\begin{tabular}{llll}
\hline $\begin{array}{l}\text { (I) GPA } \\
\text { mean }\end{array}$ & $\begin{array}{l}\text { (J) GPA } \\
\text { mean }\end{array}$ & $\begin{array}{c}\text { Std. } \\
\text { error }\end{array}$ & Sig. \\
\hline \multirow{2}{*}{1.00} & 2.00 & .13680 & .000 \\
& 3.00 & .13138 & .010 \\
2.00 & 1.00 & -.13680 & .000 \\
& 3.00 & .18272 & .002 \\
3.00 & 1.00 & -.13138 & .010 \\
& 2.00 & -.18272 & .002 \\
\hline
\end{tabular}

In table 4, 1.00 stands for students with low GPA, 2.0 for average GPA, and 3.00 for high GPA.

Comparisons between cohorts help examine trends and provide historical context. To determine the differences caused by internship year (cohort), ANOVA was used. Table 5 shows that no significant difference existed in the cohort variable $\left(\mathrm{F}_{2,50}=2.267 \mathrm{p}>0.05\right)$.

Table 5

ANOVA test for the cohort variable

\begin{tabular}{lccccc}
\multicolumn{6}{c}{ ANOVA test for the cohort variable } \\
\hline Source & SS & df & MS & F & Sig. \\
\hline $\begin{array}{l}\text { Between } \\
\text { Groups }\end{array}$ & 1.391 & 2 & .696 & 2.607 & .084 \\
$\begin{array}{l}\text { Within } \\
\text { Groups }\end{array}$ & 13.341 & 50 & .267 & & \\
Total & 14.732 & 52 & & & \\
\hline
\end{tabular}

This result indicated that students' performance in the internship program was stable and consistent. This result could be attributed to the fact that in the last three years, students went to the same institutions that offer the same internship programs. The improvement of students' performance in these programs was minor. This result shows a need to revise the internship program because the natural thing for this program is to improve over the years, not to stay stable. This finding disagrees with Frenette's (2015) findings in which he 
mentioned that a considerable rise in the prevalence and improvement of internships over years among arts graduates; in particular, that paid and unpaid internships were increasing at an equally common rate until a decade ago, when unpaid internships began growing more substantially. Among the many potential reasons for this shift is a greater demand for internships by students attempting to launch their careers during a recession. The rise in demand is also likely linked to demographic changes, especially the larger number of college-age youth. Also, the result of this study disagrees with Khalil (2015) who found that the year of the internship influenced the interns' satisfaction. Since technology is moving faster and faster, the ILTD needs to with the advancement in technology and incorporates that in the program curriculum in order to increase its effectiveness over time. Improvement in the internship program requires careful monitoring and selection of training institutions that guide students effectively. Also, students who enter the program should be selected carefully after sufficient screening and that might invite a good cohort who makes a difference. As with any worthwhile experience, developing a successful internship experience requires thought and planning. It could be beneficial if we help interns to be an integral part of the training institution from the very beginning. Providing professional networking opportunities to help a new cohort gain additional insights might increase their future performance in the internship.

\section{Conclusion and Implications}

Internship practices will continue to play a significant role in educational degree programs. Educational institutions throughout the world must strive to develop a unique, triangular partnership between students, the industry and educational institutions, forming a relationship based on intrinsic motivators and the common interests of the industry. The aim should be for an innovative, educational experience that would best fit the personality traits of individuals and, as a result, committing them to the values governing the modern technology era. The challenge for all stakeholders is to further commit to the practice and embrace new and innovative approaches that can greatly improve the development of the next digital generation; a generation that will depend more on human relations and technological skills rather than impersonal, financial considerations. Internships offer students a chance to gain a deeper understanding of one or more specialties within their chosen profession through actual work experience. As students move through their academics, classes expose them to new knowledge which stimulates their interest. They take more upper-division classes and build a skill set and some expertise within their major. This interest then manifests itself as a career option. In order to gain a better understanding of what this career option is like in reality, undergraduates participate in internship programs through their college or university. This study attempted to answer the following questions: (1) To what extent do student interns apply the second standard of ISTE for technology coaches in internship institutions as viewed by their supervisor? And (2) Do student interns' application of the second standard vary according to student interns' gender, type of internship institution, academic specialization, GPA, and internship year.

The findings of this study show that the overall performance of the students in the second ISTE standard for technology coaches has a mean value of 3.88 out of 5.00 , which reflects a reasonable and acceptable performance but not the target and desirable performance. No significant difference was observed in the application of the ISTE standard caused by gender and cohort. This study also reveals the following significant differences: type of internship institution in favor of educational institution, student GPA in favor of high GPA and average GPA in favor low GPA, and students' academic specialization in favor of learning center specialists. Based on these findings, a number of salient implications can be obtained:

- To reach the target performance (5/5) in the application of the second standard of ISTE for technology coaches, ILTD should place more courses on two elements: (f), which deal with instructional design skills and have only two courses in the degree plan, and (d), which deal with creativity, higher-order thinking skills and processes, and mental habits and which have no specific courses and are distributed over the whole program.

- Students' performance in the internship during three years shows no improvement, and this result means there is a 
need to revise the internship procedures and processes for the purposes of improvement.

- Information technology teachers require more courses on technology, such as school networking, hardware and multimedia.

- Students perform well in the use of technology tools and resources to systematically collect and analyze student achievement data, interpret results, and communicate findings to improve instructional practice and maximize students' learning. This performance should be reinforced and maintained.

- Technology integration into the classroom teaching, learning and assessment needs careful consideration when planning for effective use. Internship programs should support the innovation of technology as a tool that makes teaching more efficient and not as another layer in the curriculum.

- More research is needed in examining other standards for technology coaches.

- Further investigation could be carried on overall students' experiences on internship program.

\section{References}

Amir, T. \& Ismail, O. (2014). An evaluation of the internship program at the college of education, Sultan Qaboos University, Muscat. International Journal of Humanities, Social Sciences and Education, 1(10), 5-10.

Bacon, D. R. (2006). GPA in research studies: An invaluable but neglected opportunity. Journal of Marketing Education, 28(1), 35-42.

Barron, A., Dawson, K. \& Yendol-Hoppey, D. (2009). Peer coaching and technology integration: an evaluation of the Microsoft peer coaching program. Mentoring $\mathcal{E} T u$ toring: Partnership in Learning, 17(1), 83102.

Beard, D. F. (1998). The status of internships' cooperative education experiences in accounting education. Journal of Accounting Education, 15(2), 496 -505.

Beard, F., \& Morton, L. (1999). Effects of internship predictors on successful field ex- perience. Journalism and Mass Communication Educator, 53(4,) 42-53.

Bukaliya, R. (2012). The potential benefits and challenges internship programs in an ODL institution: a case for the Zimbabwe Open University. International Journal on New Trends in Education and Their Implications, 3(1), 118- 133. Retrieved July 22, 2014 from www.ijonte.org.

Buted, D. R., Felicen, S. S. Manzano, A.I. (2014). A Correlation Study between Student Performance in Food and Beverage Services Course and Internship in F\&B Department of Hospitality Business, International Journal of Academic Research in Business and Social Sciences, 4(6), 54-66

Bradshaw, L. (2002). Technology for teaching and learning: Strategies for Staff Development and Follow-Up Support. Journal of technology and teacher education, 10(1), 131150.

Callanan, G., \& Benzing, C. (2004). Assessing the role of internships in the careeroriented employment of graduating college students. Education and Training, 46, 82-89.

Cannon, J. A., \& Arrnold, M. J. (1998). Student expectations regarding collegiate internship programs in marketing: a 10-year update. Journal of Education for Business, 73(4), 202-205.

Casado, M. (1991). Perceptions of corporate recruiters, alumni, and educators toward critical factors of hotel/restaurant management programs: A comparative study. Unpublished doctoral dissertation. Ann Arbor: University of Michigan.

Coutinho, S. (2007). The relationship between goals, metacognition, and academic success. Educate, 7 (10), 39-47.

Divine, R., Miller, R. \& Wilson, H. (2015). Analysis of Student Performance in an Internship Program in a U.S. University. International Journal of Quality and Productivity Management, 6 (1), 1- 14.

Driscoll, J. (2006). A century of internships: A quick history of internships and co-ops in the business world. Journal of Accounting Education, 16(3), 507-516. Retrieved March 16, 2015, from 
http:/ / news.pghtech.org/teq/teqstory.cf m?id=1573education.

Felicen, S., Rasa, L., Sumanga, J. ,\& Buted, D. (2014). Internship performance of tourism and hospitality students: Inputs to improve internship program. International Journal of Academic Research in Business and Social Sciences, 4(6), 42-53.

Frenette, A. (2015). The Internship Divide: The Promise and Challenges of Internships in the Arts. SNAAP special report 2015. Retrieved September 8, 2015 from: http://snaap.indiana.edu/pdf/SNAAP15 LSNAAP_Special_Report_2015.pdf

Furco, A. (1996). Service learning and schoolto-work. Journal of Cooperative Education, 53(1), 7-14.

Gault, J., Redingtion, J., \& Schlager, T. (2000). Undergraduate business internships and career success: are they related? Journal of Marketing Education, 22, 45-53.

Hayes, D. (1981). The relationship of practicum to subsequent academic performance in a hospitality curriculum. Unpublished Doctoral dissertation, Purdue University.

Hendrikse, J. (2013). Teacher education by means of internship: A case study. Unpublished master of education, University of South Africa.

Hergert, M. (2011). Student perceptions of the value of internships in business education. American Journal of Business Education, 2(8), 9e14.

Holahan, P., Jurkat, M., \& Friedman, E. (2000, Spring). Evaluation of a mentor teacher model for enhancing mathematics instruction through the use of computers. Journal of Research on Computing in Education, 32(3), 336-350.

International Society for Technology in Education. (2012). ISTE standards for coaches. Retrieved March 1, 2015, from http:/ / www.iste.org/standards/ISTEstandards/standards-for-coaches.

Ju, J., Emenheiser, D., Clayton, H., \& Reynolds, J. (1998). Korean students' perceptions of the effectiveness of their internship experiences in the hospitality industry in Korea. Asia Pacific Journal of Tourism Research, 3(1), 37-44.
Khalil, O. (2015). Students' experiences with the business internship program at Kuwait University. The International Journal of Management Education 13, 202-217

Kim, E. B., Kim, K., \& Bzullak, M. (2012). A survey of internship programs for management undergraduates in AACSBaccredited institutions. The InternationalJournal of Educational Management, 26(7), 696-709.

Littke, D. (2004). The big picture: Education is everyone's business. Alexandria, VA: Association for Supervision and Curriculum Development.

Cynthia Martinez ,C., Lontoc, J. Villena , A. \& Laguador, J. (2014). Correlation of OnThe-Job training performance on print media of $\mathrm{AB}$ mass communication students and academic performance in selected professional courses for school Year 2012-2013. Journal of Education and Literature, 2 (3), 2 80-88

McMahon, U., \& Quinn, U. (1995). Maximizing the hospitality management student work placement experience: A case study. Education and Training, 37, 13-17.

Merritt, R. (2008). Student internships. EBSCO research starters. Retrieved September 30, 2015 from

https://www.ebscohost.com/uploads/im ported/thisTopic-dbTopic-1072.pdf

Parsa, S., Aghazadeh , A., Nejatisafa, A., Amini, H., Mohammadi, M., Mostafazadeh , B., Moghaddam, Y. (2010). Freshmen versus Interns' Specialty Interests. Archives of Iranian Medicine, 13(6), 509-514.

Streumer, J. N., and Kho, M. (2006). The world of work-related learning. In Streumer, J. N. (ed.), Work-Related Learning, pp 211230, Springer.

Swan, B. \& Dixon, J (2006). The effects of mentor-supported technology professional development on middle school mathematics teachers' attitudes and practice. Contemporary Issues in Technology and Teacher Education [Online serial], 6(1). Retrieved September 8, 2015

from http://www.citejournal.org/vol6/is s1/mathematics/article1.cfm.

Thiel, G. \& Hartley, N. (1997). Cooperative education: A natural synergy between 
business and academia. SAM Advanced Management Journal, 62, 19-24.

Walo, M. (2001).Assessing the contribution of internship in developing Australian tourism and hospitality students' management competencies. Asia Pacific Journal of Cooperative Education, 2 (2), 12-28. retrieved September 9, 2015 from http://www.apjce.org/files/APJCE_02_2 _12_28.pdf, Asia Pac

Wynn, J. R. (2003), High school after school: Creating pathways to the future for adolescents. New Directions for Youth Development, 97, 59-74. doi: 10.1002/yd.35

Retrieved February 16, 2015, from http://onlinelibrary.wiley.com/doi/10.10 02/yd.35/epdf.

Yeswa, E., Okaka, O., Mutsotso, S., Odera, O. \& Mumbo, H. (2012). Impact of Internship Programme on the Performance of Public Health Care Institution. Global Journal of human social science arts $\mathcal{E}$ Humanities, 12 (13) $1,39-44$. 


\section{Appendix 1 \\ ISTE Second standard for technology coaches \\ Teaching, Learning, and Assessments of Technology}

Technology coaches assist teachers in using technology effectively for assessing student learning, differentiating instructions, and providing rigorous, relevant, and engaging learning experiences for all students.

a. Coach teachers in and model design and implementation of technology-enhanced learning experiences addressing content and student technology standards.

b. Coach teachers in and model design and implementation of technology-enhanced learning experiences using a variety of research-based, learner-centered instructional strategies and assessment tools to address the diverse needs and interests of all students.

c. Coach teachers in and model engagement of students in local and global interdisciplinary units in which technology helps students assume professional roles, research realworld problems, collaborate with others, and produce products that are meaningful and useful to a wide audience.

d. Coach teachers in and model design and implementation of technology-enhanced learning experiences emphasizing creativity, higher-order thinking skills and processes, and mental habits (e.g., critical thinking, metacognition, and self-regulation).

e. Coach teachers in and model design and implementation of technology-enhanced learning experiences using differentiation, including adjusting content, process, product, and learning environment based upon student readiness levels, learning styles, interests, and personal goals.

f. Coach teachers in and model incorporation of research-based best practices in instructional design when planning technology-enhanced learning experiences.

g. Coach teachers in and model effective use of technology tools and resources to continuously assess student learning and technology literacy by applying a rich variety of formative and summative assessments aligned with content and student technology standards.

h. Coach teachers in and model effective use of technology tools and resources to systematically collect and analyze student achievement data, interpret results, and communicate findings to improve instructional practice and maximize students' learning. 